\title{
An unusual cause of neonatal cyanosis...
}

\author{
Raquel Carreira, ${ }^{1}$ Maria João Palaré, ${ }^{2}$ Ana Rita Prior, ${ }^{3}$ Paula Garcia, ${ }^{4}$ \\ Margarida Abrantes ${ }^{2}$
}

1 Department of Pediatrics, Hospital Santa Maria, Centro Hospitalar Lisboa Norte, EPE, Lisbon Academic Medical Center, Lisbon, Portugal ${ }^{2}$ Pediatric Hematology Unit. Department of Pediatrics, Hospital Santa Maria, Centro Hospitalar Lisboa Norte, EPE, Lisbon Academic Medical Center, Lisbon, Portugal

${ }^{3}$ Neonatology Unit, Department of Pediatrics, Hospital Santa Maria, Centro Hospitalar Lisboa Norte, EPE, Lisbon Academic Medical Center, Lisbon, Portugal ${ }^{4}$ Neonatology Unit, Hospital da Luz, Lisbon, Portugal

Correspondence to Dr Ana Rita Prior, anaritaprior@gmail.com

Accepted 13 February 2015

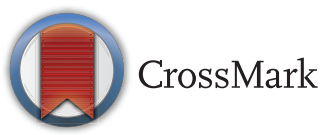

To cite: Carreira $\mathrm{R}$, Palaré MJ, Prior AR, et al. BMJ Case Rep Published online: [please include Day Month Year] doi:10.1136/ bcr-2014-208371

\section{SUMMARY}

We report a case of a female neonate whose pulse oximetry screening for congenital heart disease at $40 \mathrm{~h}$ of life was positive. The pregnancy was uneventful with no relevant family history. The neonate presented with bluish discolouration of the skin lasting until day 15.

Cardiovascular examination and chest radiography were normal. Septic screening was negative. Oxygen therapy was started with poor response; investigations revealed a methaemoglobinaemia of $7.4 \%$. The methaemoglobin level reached a peak of $15 \%$ on day 10 , falling thereafter. The infant was discharged by day 20 with a normal physical examination and a methaemoglobinaemia of $11.4 \%$. By 2 months of age this had fallen to $2.4 \%$. Further investigation revealed a haemoglobin $\mathrm{M}$ variant: a heterozygous mutation of the $\gamma$ globin gene known as $\mathrm{Hb}$ F-M Viseu. The mutation occurs in the $\gamma$ chain, therefore the methaemoglobinaemia is transitory, resolving with the transition from fetal to adult haemoglobin.

\section{BACKGROUND}

Neonatal cyanosis can be an important diagnostic challenge. Causes are variable including infectious, cardiac or respiratory diseases. Although rare, cyanosis may be associated with methaemoglobinaemia and therefore this diagnosis must be considered when the more common causes are excluded.

Methaemoglobinaemia is a condition in which the iron within the haemoglobin $(\mathrm{Hb})$ molecule is oxidised from the ferrous $\left(\mathrm{Fe}^{2+}\right)$ to the ferric $\left(\mathrm{Fe}^{3+}\right)$ state and for this reason cannot bind oxygen; ${ }^{12}$ in addition, methaemoglobin (MetHb) shifts the oxygen- $\mathrm{Hb}$ dissociation curve to the left, hindering the release of $\mathrm{O}_{2}$ in tissues. ${ }^{3}$ These two conditions compromise the oxygen exchange and supply to tissues, causing a cyanosis that does not resolve with oxygen therapy, which is a clue to the diagnosis.

Methaemoglobinaemia can be acquired from exposure to several oxidising agents, or congenital, due to a deficiency of cytochrome b5 reductase activity or the presence of $\mathrm{M}-\mathrm{Hb}{ }^{4}{ }^{4}$ The latter is illustrated in our clinical case: hypoxaemia and cyanosis in a neonate associated with a mutation in the $\gamma$ chain of $\mathrm{Hb}$, known as $\mathrm{Hb}$ F- M Viseu.

\section{CASE PRESENTATION}

We describe the case of a female neonate, first child of a non-consanguineous couple, born at 38 weeks of gestational age by vacuum-assisted delivery, weighing $2680 \mathrm{~g}$. The Apgar scores were 9 and 10 at 1 and $5 \mathrm{~min}$, respectively. The pregnancy was uneventful and there was no relevant family history, specifically no history of congenital heart disease or neonatal cyanosis.
The infant was asymptomatic until $40 \mathrm{~h}$ of life, when neonatal pulse oximetry screening for congenital heart disease detected hypoxaemia with saturations of $88-89 \%$. On clinical examination, there was no respiratory distress, however, she had a mild cyanosis that persisted until day 15 . Septic screening was negative, echocardiography and chest radiography were normal. She was started on oxygen therapy without improvement. A MetHb level of $7.4 \%$ was found and on the sixth day of life the baby was transferred to a tertiary hospital for further investigation. MetHb rose to a maximum of $15 \%$ on day 10 and thereafter the level decreased slowly. She was discharged at 20 days of age with a normal clinical examination, good weight gain and a MetHb level of $11.4 \%$.

Contact with chemical agents or medications known to cause the acquired form of methaemoglobinaemia was excluded.

\section{INVESTIGATIONS}

- Basal complete blood count: Hb $16.3 \mathrm{~g} / \mathrm{dL}$, erythrocytes $4.52 \times 10^{12} / \mathrm{L}$, mean globular volume $109.9 \mathrm{fL}$, mean globular $\mathrm{Hb} 36.1 \mathrm{pg}$, reticulocytes $90 \times 10 / \mathrm{L}$, normal peripheral blood smear.

- Hb electrophoresis at day 7: normal (HbF 85\%).

- Arterial blood gas analysis at day 13: $\mathrm{pH} 7.41$, partial pressure of carbon dioxide $\left(\mathrm{pCO}_{2}\right)$ $41.5 \mathrm{~mm} \mathrm{Hg}$, partial pressure of oxygen $\left(\mathrm{pO}_{2}\right)$ $141 \mathrm{~mm} \mathrm{Hg}$, bicarbonate $\left(\mathrm{HCO}_{3}\right) 26.5 \mathrm{mmol} / \mathrm{L}$, $\mathrm{Hb} 12.5 \mathrm{mg} / \mathrm{dL}, \mathrm{MetHb} 13.1 \%$, arterial oxygen saturation $\left(\mathrm{SaO}_{2}\right) 99 \%$.

- Glucose-6-phosphate dehydrogenase and pyruvate kinase activity assays: normal.

- Cytochrome b5 reductase activity: $3.0 \mathrm{UI} / \mathrm{gHb}$ (adult control: $3.5 \mathrm{UI} / \mathrm{gHb}$ ).

- Sequence analysis of the $\beta$ globin genes: normal.

- Sequence analysis of the $\gamma$ globin genes: heterozygous mutation at the $\mathrm{HBG}$ gene (c. $85 \mathrm{C}>\mathrm{A}$; p.Leu29Met) known as $\mathrm{Hb}$ F- M Viseu.

\section{TREATMENT}

Oxygen therapy was started based on the peripheral oxygen saturation $\left(\mathrm{SpO}_{2}\right)$, with no significant increase in this parameter. Serial measurements of arterial blood gases without supplemental oxygen revealed saturations of $>93 \%$ and so therapy was discontinued.

By day 10 the infant was started on oral ascorbic acid $(25 \mathrm{mg} /$ day $)$, which was discontinued at 2 months of age.

\section{OUTCOME AND FOLLOW-UP}

At discharge, the infant was referred to the haematology outpatient clinic and during the follow-up 
she was asymptomatic, without clinical evidence of cyanosis. MetHb levels decreased significantly (6 weeks: 5.5\%; 2 months: $2.4 \%)$.

The family was referred to genetic outpatient clinic but were lost to follow-up.

\section{DISCUSSION}

In this clinical case we present a newborn with hypoxaemia and cyanosis. Since cardiac, respiratory and infectious causes were excluded and cyanosis did not improve with administration of supplemental oxygen, methaemoglobinaemia was suspected. Laboratory evaluation confirmed a raised serum MetHb level.

Deficiency of cytochrome b5 reductase is the most common cause of congenital methaemoglobinaemia. It is an autosomal recessive disorder divided into two types. Type I, the most common, affects only erythrocytes, and type II affects all cell lines. ${ }^{5}$ In our clinical case, the assay used to quantify cytochrome b5 reductase activity showed a value of $3.0 \mathrm{UI} / \mathrm{gHb}$ compared with an adult control of $3.5 \mathrm{UI} / \mathrm{gHb}$, this was seen as normal because in neonates $\mathrm{MetHb}$ reductase levels can be as low as $60 \%$ of the adult values. ${ }^{4}$

$\mathrm{Hb} \mathrm{M}$ disease is the other major cause of congenital methaemoglobinaemia. In this condition, mutations affect the globin chain of $\mathrm{Hb}$, resulting in resistance to reduction by cytochrome b5 reductase. ${ }^{5}$ When the mutation affects the $\alpha$ chain the cyanosis is present at birth, when the $\beta$ chain is affected cyanosis usually starts at 6 months (although it can present earlier) when most of $\mathrm{HbF}$ has been replaced by $\mathrm{HbA}$. When the mutation affects the $\gamma$ chain, the cyanosis can be present at birth and the methaemoglobinaemia is transient due to the physiological transition from fetal $\mathrm{Hb}(\mathrm{HbF} \alpha 2 \gamma 2)$ to adult $\mathrm{Hb}(\mathrm{HbA} \alpha 2 \beta 2) .{ }^{6}$ In our clinical case, the $\mathrm{Hb}$ electrophoresis was normal but the clinical suspicion remained. Globin chain gene sequencing was performed because some $\mathrm{Hb}$ variants are electrophoretically silent. ${ }^{6}$ A heterozygous mutation at the $\mathrm{HBG}$ gene $(85 \mathrm{C}>\mathrm{A}$; p.Leu29Met) known as Hb F-M Viseu was identified. Hb F-M variants are very rare conditions. In the literature only six different $\mathrm{G} \gamma$-chain variants were identified: Hb-FM Osaka, Hb-FM Fort Ripley, Hb-FM Circleville, Hb-F Cincinnati, Hb-FM Toms River and Hb-FM Viseu. ${ }^{6}$ The Hb-FM Viseu mutation was first described in 2012 and was named 'Viseu' after the patient's hometown. It results from a leucine substitution at residue 28 , located in the heme pocket near the H63 residue. ${ }^{6}$ Because it occurs in the $\gamma$ chain, as in our patient, the methaemoglobinaemia is supposed to be transient with MetHb levels showing a significant decline over time.

Signs and symptoms of methaemoglobinaemia are variable, depending on the percentage of MetHb. Cyanosis generally occurs when at least $10 \%$ of $\mathrm{Hb}$ is in the MetHb form. At higher levels (>30\%) of MetHb, patients may have respiratory distress and altered mental status. ${ }^{3} 5$ Patients with congenital disease develop physiological adaptation and can tolerate higher levels of MetHb (up to 40\%) without symptoms; nevertheless, when exposed to oxidative agents, these patients can present clinical decompensation. ${ }^{5}$

In patients with methaemoglobinaemia arterial blood gas analysis reveals a high partial pressure of $\mathrm{O}_{2}$ with a normal $\mathrm{SaO}_{2}$, well above saturation given by pulse oxymetry. ${ }^{5}$

There is no specific treatment for congenital methaemoglobinaemia. ${ }^{6}$ It is important to avoid the administration of oxidative compounds that can raise MetHb causing clinical decompensation. ${ }^{5}$ Methylene blue is the treatment of choice for severe methaemoglobinaemia. It is a thiazine dye with dose-dependent antioxidising properties. In the presence of nicotinamide adenine dinucleotide phosphate (NADPH), methylene blue is converted to leucomethylene blue, which results in non-enzymatic reduction of MetHb. ${ }^{4}$ Nevertheless, this therapy has limited effect in $\mathrm{Hb} \mathrm{M}$ disease; only patients with deficiency of cytochrome b5 reductase have a good response to the treatment. ${ }^{5}$ Ascorbic acid is an antioxidant and coenzyme for reduction. It may be helpful in the treatment of congenital methaemoglobinaemia if used daily and on a continual basis but the rate of the reaction is slow. If the combination of methylene blue and ascorbic acid fails to reduce the MetHb level, hyperbaric oxygen and exchange transfusions are alternative therapies. ${ }^{4}$ In our case, we decided to introduce ascorbic acid because it has few side effects and may help to improve MetHb levels.

The genetic evaluation is important because this condition has an autosomal dominant pattern of inheritance. Of note in this case, the father's family is from the town of Viseu, the same geographical location of the previous case of this mutation described in the literature. ${ }^{6}$

This case report shows a rare cause of neonatal cyanosis that should be considered in the differential diagnosis of a cyanotic newborn, especially when the more common causes are excluded. Invasive procedures or tests could be avoided in a well-appearing cyanotic baby with modestly elevated MetHb, a normal arterial $\mathrm{pO}_{2}$ and no signs of cardiopulmonary disease.

\section{Learning points}

- Methaemoglobinaemia is a rare cause of neonatal cyanosis.

- The two main causes of congenital methaemoglobinaemia are cytochrome b5 reductase activity deficiency and $\mathrm{M}$-haemoglobin (M-Hb) variants.

- Some of the $\mathrm{Hb}$ variants have a normal electrophoresis and the diagnosis has to be made by sequencing the globin chain gene.

- In this case report, the mutation occurred in the $\mathrm{Hb} \gamma$ chain and, therefore, the methaemoglobinaemia is temporary due to the physiological transition from fetal $\mathrm{Hb}\left(\mathrm{HbF} \alpha 2 \gamma_{2}\right)$ to the adult $\mathrm{Hb}(\mathrm{HbA} \alpha 2 \beta 2)$.

Competing interests None.

Patient consent Obtained.

Provenance and peer review Not commissioned; externally peer reviewed.

\section{REFERENCES}

1 Mansouri A, Lurie AA. Concise review: methemoglobinemia. Am J Hematol 1993;42:7-12.

2 Percy MJ, McFerran NV, Lappin TR. Disorders of oxidised haemoglobin. Blood Rev 2005;19:61-8.

3 Nelson K, Hostetler M. An infant with methemoglobinemia. Hosp Physician 2003;62:31-8

4 Da-Silva S, Sajan I, Underwood J. Congenital methemoglobinemia: a rare cause of cyanosis in the newborn-a case report. Pediatrics 2003;112:158-60.

5 Nascimento T, Pereira R, Mello H, et al. Metemoglobinemia: do diagnóstico ao tratamento. Rev Bras Anestesiol 2008;58:651-64.

6 Bento C, Magalhães Maia T, Carvalhais I, et al. Transient neonatal cyanosis associated with a new Hb F variant: Hb F viseu. J Pediatr Hematol Oncol 2013;35(2): e77-80. 
Copyright 2015 BMJ Publishing Group. All rights reserved. For permission to reuse any of this content visit http://group.bmj.com/group/rights-licensing/permissions.

BMJ Case Report Fellows may re-use this article for personal use and teaching without any further permission.

Become a Fellow of BMJ Case Reports today and you can:

- Submit as many cases as you like

- Enjoy fast sympathetic peer review and rapid publication of accepted articles

- Access all the published articles

- Re-use any of the published material for personal use and teaching without further permission

For information on Institutional Fellowships contact consortiasales@bmjgroup.com

Visit casereports.bmj.com for more articles like this and to become a Fellow 